\title{
The Positive Impact of Macau Low-cost Carriers to Enhance Regional Tourism Economy
}

\author{
Xin Wang ${ }^{1}$, Chia Hsin Leou ${ }^{1} \&$ Jiayi $\mathrm{Li}^{2}$ \\ ${ }^{1}$ Faculty of International Tourism and Management, City University of Macau, Macau \\ ${ }^{2}$ MBA-Accounting, School of Business, Johnson \& Wales University, United States \\ Correspondence: Xin Wang, Faculty of International Tourism and Management, City University of Macau, Edifício \\ Choi Kai Yau - N Building, $5^{\circ}$ Andar, Avda. Padre Tomás Pereira, Taipa, Macau.
}

Received: July 28, 2016

doi:10.5430/jms.v7n4p11
Accepted: August 7, 2016

Online Published: October 28, 2016

URL: http://dx.doi.org/10.5430/jms.v7n4p11

\begin{abstract}
It is certainly that Low-cost carriers could come out during the time tourism being popularized. Also it is a way that being used to occupy market shares and increase purchase rate among potential customers. Meanwhile, the development of low-cost carriers is changing the segment market and direction in air industry by re-integration the function of regional tourism, cooperate and segregate in tourist destination. It becomes a trend as complementary development between low-cost carriers and tourism industry. In the future, we should focus on building an entire low-cost carriers tourism system, improving low-cost carriers' specialized products, in order to meet win-win requirement among low-cost carriers and regional tourism.
\end{abstract}

Keywords: Macau low-cost carriers, regional tourism economy, strategies

\section{Introduction}

\subsection{Current Situation of Macau}

Macau has become known worldwide as the "Monte Carlo of the Orient" since Portuguese government legalized gambling in the colony in 1850s. The business has expanded rapidly since the government ended gambling monopoly in 2002, gambling became the biggest source of revenue in Macau. However, the business started grow slowly after June 2014, and related evaluate organizations like Morgan Stanley even predicted that revenue from gambling will be consistently reduce by $4 \%$ in 2005 . The fact reflects that gambling only cannot make contribution to sustainable development, Macau should come up a solution to establish a diverse industry of tourism. Back to 2009, some public voice had already raised a proposal about to create Macau as a "World's center of Leisure and Entertainment". However, The World Heritage Site, cultural tourism and other tourism attractions are not well-known comparing with gambling which has always been paying highly attention to.

On the other hand, according to the official data, the overall amount of visitors in 2014 had been increased. However, there are not sufficient data about visitors' consuming behavior, including mode of transportations, same-day visitors, hotel rooms' occupancy rate, per-capita spending of visitors, as well as tourism attractions.

\subsection{Macau Aviation Development History}

January 18, 1891, Mr. Thomas Baldwin, witness hot air balloon flight safety, he filled balloon with hot air, balloon then took off, he even did gymnastics over 3000 feet in the cloud. The launching of a hot balloon and a safely landing, made Macau the very first flight records. In 1920, Charles Ricou from French founded "Macau Aerial Transport Co. (MAT)" in Macau, Shuttle program made Macau as a base site and located in Taipa Beian, the company purchased twelve retired water aircraft from US Navy, for private entertainment and operating the route between Hong Kong, China and neighboring regions. MAT eventually closed in 1922, its aircraft were took over by the government of Macau. In 1937, 10 A.M. On 27 April, the thunder boat Sikorski S42 from Pan American airline landed after circled above Macau, represent the route between United States and Macau officially launched. More than two thousand guests attend the inaugural ceremony, including representatives of the governor of Macau. Macau post office even set up a temporary office at the airport, to do telegram service for the public, and this is the first time that Macau has its air mail service. Until 1939, Macau station was officially ended by Pan American. 


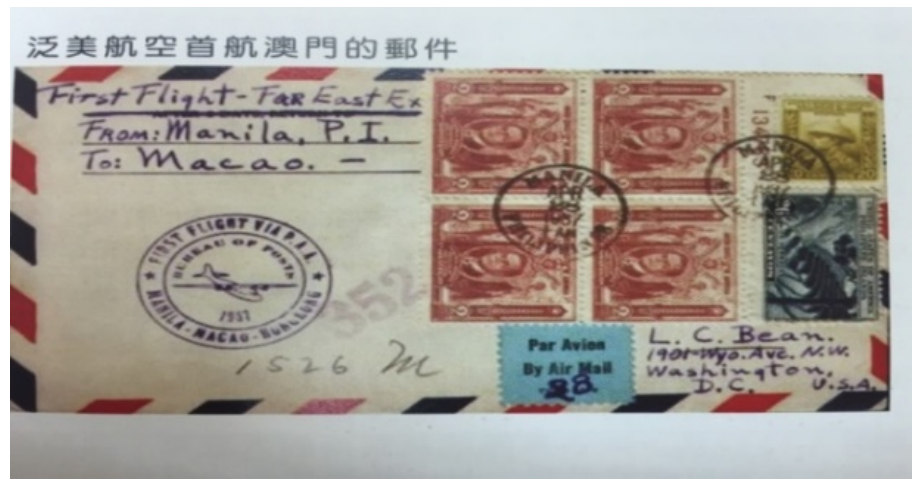

Figure 1. The mail of Pan American Airline's first flight to Macau

After the end of World War II, with the chaos of the regional financial system, combined with the Chinese civil war, there were a lot of gold financial import and export of Hong Kong daily, Portugal is not Bretton Woods convention member, thus not subject to the control of gold. The newly established airline - Cathay Pacific Airways seized the opportunity to operate the route of Macau. Seaplane were used to operate the route between Macau and Hong Kong. In 1961, Paul as one of the founders of Macau air transport, ordered a double engine five seat P-136L amphibious plan from Italy, from Macau airport to Hong Kong Kai Tak airport, one way fare is HK $\$ 50$, due to rapid development of high speed hydrofoil with much cheaper price, Macau air Transport Company finally closed in 1964. Yet, this classic route was operated by Asia Pacific Airlines at present, AW139 helicopter services currently, 15 -minute single trip distance at the price of MOP\$1,900 (about US\$275), most of the passengers are busy businessman and big spender (Illustrate handbook of Macau civil aviation, 2012)

\subsection{Macau Airport}

\subsubsection{The History of Macau International Airport}

After the World War II, several governor of Macau proposed the construction of an international airport in Macau. In 1987, the new governor decided to build Macau International Airport at the end of Taipa area by the means of land reclamation. November 18, 1995, Malaysia Airlines B737-400 aircraft from the capital of Malaysia - Kuala Lumpur, safely landing at the local time 12:10 at the Macau International Airport, made the first commercial flight landed at Macau International Airport. December 1st of the same year, Taipei air transport business association and Macau airlines signed the "Air transport agreement between Tai Wang and Macau", Macau has become the main transfer station on both sides of the Strait, and passengers from Tai Wang can transfer directly to the domestic flight to the mainland of China via Macau. December 18, Macau International Airport announced operation officially, represents Macau aviation industry step into a brand new era. Macau International Airport was designed according to the "CAT" standard of International Civil Aviation Organization. The terminal building is 50 thousand square meters, nineteen helipads, four of them attached to the boarding bridge and multi-storey park area with 600 parking lots. Macau International Airport operates twenty-four hours a day. The second instrument with land system and full-length of thousand feet runway, available for Boeing 747 aircraft movements. The area of terminal building is 4,500 square meters; the design capacity is 6 million passengers per year. In 2015, Macau International Airport passenger transportation volume reached 583 million, airport flight movements sorties over 5.2 million times; airport jet lifting vehicles are 2,791 sorties. Macau International Airport is the worldwide air bridge of Macau, plays the main social functions in cooperate with regional economic development and promote regional integration, and plays a vital role to enhance the international visibility, promote the economic development and long-term prosperity and stability of Macau. Macau International Airport official website strive to provide more quality and convenient information for visitors in five languages of Chinese, English, Portuguese, Japanese, and Korean. 


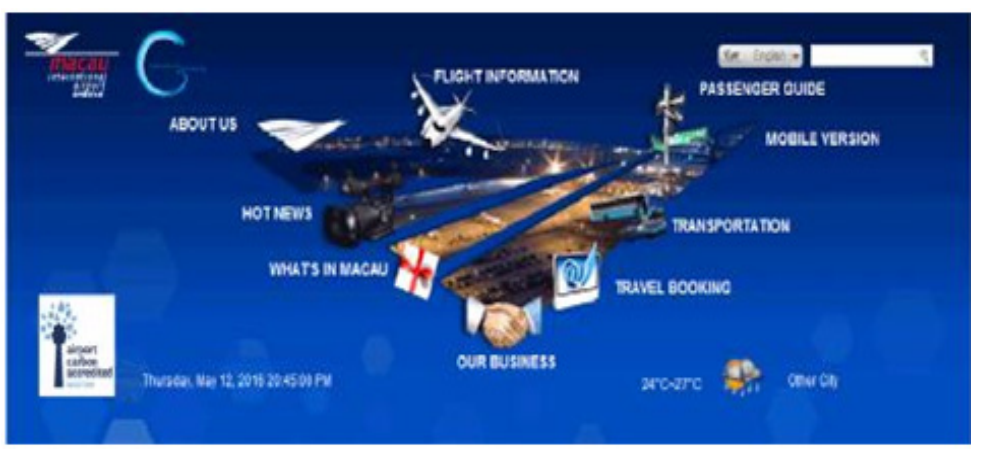

Figure 2. Screen shot of Macau airport home page

\subsubsection{A5 Airport Group}

In the Pearl River Delta with a radius of less than two hundred km, there are five international airports - Hong Kong, Guangzhou, Shenzhen, Macau and Zhuhai. A5 airport alliance was established on the purpose of mutual cooperation enhancement. The goal of A5 airport group establishment is to segment the market through difference positioning, reduce friction and realize the sharing of resources, participate in international competition through coordinated operations. Since 2001, "Seminar of Pearl River Delta A5 airport group" has been held to confront challenges, strengthen exchanges and cooperation, and promote mutual development. In 2007, A5 airport group held "Pearl River Delta Cooperation Forum", jointly signed "Outline of the reform and development of the Pearl River Delta region" at Guangzhou in March 2009, to reach a consensus, the outline including six aspect of development and positioning, jointly expand the Pearl River Delta airspace and carry out exchanges and cooperation actively. Fight for expanding the PRD airspace, making the Greater Pearl River Delta region as national low open sky test area.

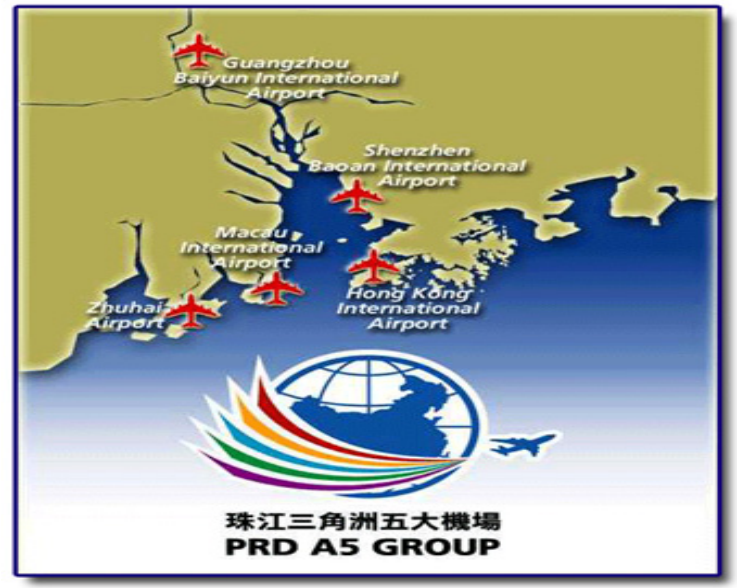

Figure 3. Pearl River Delta A5 group

\subsubsection{Airlines in Macau}

At present, there are 26 airlines operating at Macau international airport, suchas Air Macau, Eastern Airlines, Shanghai Airlines, Air China and Spring Airlines etc. 


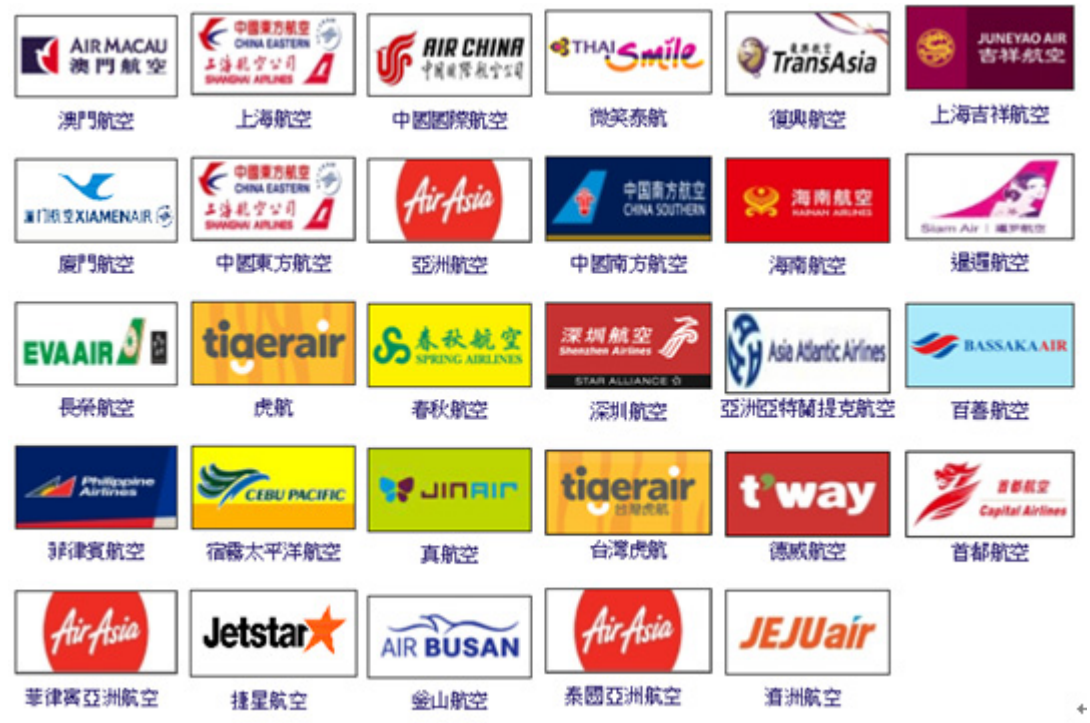

Figure 4. Airlines in Macau

\section{Macau Low-cost Carriers}

In July 5, 2004, the first flight of Thai Air Asia from Bangkok to Macau, represented Macau Airport entered the age of low cost airlines. Low-cost carriers, such as Tiger Air and Jet Star from Singapore, Cebu Pacific of Philippine opened their route to Macau one after another. Later on, Macau also established its first low-cost carrier Viva airlines. There are 29 airlines operating in Macau currently, of which the low-cost airlines are 15, responsible for half of the Macau aviation passenger transportation.

Table 1. Macau low-cost carriers list

\begin{tabular}{|c|c|c|c|c|}
\hline Airline Name & Owner Nation & $\begin{array}{c}\text { First Flight to } \\
\text { Macau(Year) }\end{array}$ & Flight Route & $\begin{array}{c}\text { Frequency/ } \\
\text { Week }\end{array}$ \\
\hline Air Asia & Malasia & 2004 & Bangkok/Chiengmai/Pattaya/ & 63 \\
\hline Tai Wang Tiger Air & Singapo & 2014 & Taipei/Gaoxiong - Macao & 26 \\
\hline Jet Star & Singapo & - & Nha Trang/Da Nang - Macao & 14 \\
\hline Spring Airlines & China(mainland) & 2011 & Shanghai - Macao & 12 \\
\hline Cebu Pacific & Philipins & 2007 & Clark/Manila - Macao & 11 \\
\hline Tiger Air & Singapo & - & Singapore - Macao & 10 \\
\hline Jin Air & Kora & 2009 & Seoul - Macao & 7 \\
\hline Thai Smile & Thailand & 2012 & Bangkok - Macao & 7 \\
\hline Siam Air & Thailand & - & Bangkok - Macao & 7 \\
\hline JUNEYAO Air & China(mainland) & - & Shanghai - Macao & 6 \\
\hline Air BUSAN & Kora & 2012 & Busan - Macao & 3 \\
\hline T'way Airlines & Kora & - & - & 0 \\
\hline Eastar Jet & Kora & 2011 & - & 0 \\
\hline V Air & Tai Wang & 2015 & - & 0 \\
\hline Air Asia Zest & Philipins & - & - & 0 \\
\hline
\end{tabular}

(Data source: Information are collated from the official website of Macau International Airport, data statistics up to May 2016)

The departure cities of these low-cost carriers, are almost the major Asian cities, such as Beijing, Shanghai, Singapore, Manila, Kaohsiung, Taipei, Kuala Lumpur, Bangkok, Seoul, Incheon, Busan and so on. The passengers who take low cost airlines headed to Macau, a part of them take Macau as their final destination, for those passengers, 
low cost airlines provide them a cheaper and convenient choice; and for another part of passengers who had never planned travel to Macau, because of the cheaper tickets of low-cost carrier, push them travel to Macau or take the Macau as a transit. In terms of market share proportion, the biggest share of the Southeast Asian market in Macau passengers, reached $32 \%, 40 \%$ in mainland China, and Taiwan is $28 \%$.

Macau is the first region to bring in low-cost carrier in area China, low-cost carriers has been promoted as differentiated marketing strategy over the years. So far, Macau has attracted 15 low-cost carriers around the world to put into operation, covering 22 destinations in Southeast Asia. Low-cost carriers have experienced more than ten years of development in Macau, it becoming mature, and be a kind of rigid demand in Macau. The success of low-cost carriers in Macau, and a considerable market share in Asian countries today, fully verified the successful strategic of LCC development. The strong policy support from mainland China provides a stable and powerful environment for the civil aviation industry in Macau, coupled with Macau's unique geographical location, making low cost airlines grow with Macau as a "World Tourism and leisure center" positioning together, bearing and attracts tourists of worldwide. After years of efforts, an increasing number of passenger take Macau as their tourism destination, passengers of low-cost carriers occupy $31 \%$ of the total. Low-cost carriers are a great power of generator for Macau's diversify economy development.

\section{The Positive Effects of Low-cost Carriers}

\subsection{Promote Segregation and Cooperation of Tourist Destination}

It is positive that low-cost carrier will affect segregation of specialized area in each tourist destination, then the category of tourist destination would be divided into tourism distributing center, sightseeing district, leisure destination, tourism main functional zone, in order to complete regional industry chain.

\subsection{Achieve Beneficial Revolution by Promoting Regional Tourism Development}

It is forced to change the pattern and direction of developing as regional districts and local corporations with the development of low-cost carriers. It is even more challenging to the place where would like to promote development by offering free admission tickets. The market concept will transform from occasionally to normally, aristocratic to popular, sightseeing to leisure; also related marketing media and idea would be adjusted along with the change. So that low-cost carriers would be given a unique marketing value in tourism industry.

Low-cost carriers may help pushing forward the development of regional tourism, meanwhile, low-cost carriers do need support from tourism industry. Tourism development plan should take transportation revolution into consideration, likewise, it also should be pay attention to routes design by focusing on peak and off seasons, spatial characters and scale.

\subsection{Route Network in Macau}

Macau has a good foundation of air rights, there are 47 navigable cities of Macau International Airport, including Taipei, Bangkok, Manila, Singapore, Malaysia, Kuala Lumpur, Seoul, Clark, Beijing, Shanghai, Chengdu, Kunming, Nanjing etc., there are up to 57 cities opened to Macau from mainland China, but currently only 22 of them are navigable, while most of the visitors travel to Macau are from mainland China. Until now, Macau Special Administrative Region has discussed the flight agreement with 45 countries, and 39 of the agreements have been signed, thus the space of route expanding is very broad. Furthermore, Macau has the authority of flexibility autonomy air traffic right from central government, available to sign agreement with mainland China and other countries independently for air traffic rights opening. Qing Li and Weiwei Li (2010) made suggestion for Macau future aviation industry that open more mainland routes; open route to Europe; increase the weekend flights; expand Macau international airport; enhance the competitive advantage of Macau airlines. The SAR government recently announced the Construction of the world tourism leisure center five years planning, Concentration is on how to improve the Macau's tourism and leisure environment, and it inevitably involves the routes and flight of the international airport. To attract more international airline, affords need to make on infrastructure perfection, international customers increasing, and reception capacity improvement.

\subsection{Airline Industry Cooperation between Macau-Guangdong and Macau-Portugal}

March 6, 2011, the government of the Macau special administrative region in signed the way cooperation framework agreement (hereinafter referred to as the "framework agreement") with Guangdong provincial government in Beijing, for two sides cooperation and Macau economic development, meanwhile opened up a new space and brought more opportunities for the development of Macau aviation industry. The framework agreement raised the Pearl River Delta region and the Macau SAR up to the level of national strategic cooperation, provides policy support for Macau 
in regional cooperation. Hong Kong-Macau-Zhuhai Bridge is going to operate soon, promote the cooperation and development for three regions, is conducive to ease the pressure of the environment and airspace of third runway construction of Hong Kong international airport, and expand the development space of Macau local tourism, logistics, trade, finance, service industries etc.

In 2010, Macau international airport successfully held the third China and Portuguese-speaking countries airport meeting, five copies of cooperation agreement and memorandum have been signed. Since the first meeting held in 2004, the meeting mechanism between China and the Portuguese-speaking countries airport vigorously promoted in Portugal Macau air control and airport management personnel training program of communication, give full play to the role of the mainland exchange platform with Portuguese-speaking countries. Through transport infrastructure cooperation, promote passenger transit, logistics, and capital flow and information exchange, promote the development of the regional integration, to create the world tourism leisure center of energy and moderately to Macau economy development. Recently, professors of Macau civil aviation put forward a series of reform ideas, firstly is to utilize the fifth right and beyond right, to shift the Macau international airport from multifunctional small international airport to China international gate airport that connect with Portuguese-speaking countries. This idea completely conforms to the positioning of the Macau special administrative region, and closely cooperates with the "B\&R" international strategy.

\section{Regional Tourism Development Strategies}

\subsection{Provides "Low-cost Airline + Hotel" as Self-service Travel Products}

Since we could take good advantage of value of channels and integration, in order to build discount package like "low-cost airlines + hotel" and "low-cost airlines + attractions". Those packages not only offering discounts for customers, but also expanding market for related corporations and making low-cost carriers more attractive to potential customers.

Based on overall output of low-cost carriers, it provides a beneficial condition of building "low-cost airlines tourism" brand image through improving innovation of ticketing services in order to ensure the seats occupancy. At the same time, selling costs could be reduced by authorize agencies, social media, and advanced sales software.

\subsection{Multiply Tourism-themed Products Exhibition}

In order to complete tourism-themed products in a future short period of time, we should emphasize the development of chartered airplane products. Because chartered airplane products could not only increase the total number of visitors and operating income, but also gain fiscal revenue for local government as well as facilitate domestic employment.

We should take good advantage of resources within airlines routes, by design tourist plan together with travel agencies for holiday seasons, establish a complementary development with traditional airlines. Stable supply could easily satisfy market demands; it is good for promoting tourism products as well.

\subsection{Establish Multi-departments Corporative Mechanism}

It is feasible that tourism department could establish corporative mechanism with low-cost carriers, launch tourism related researches, follow up the construction of tourism distributing center, support tourism products become branding and collectivize, co-holding tourism seminars and national low-cost carrier exhibitions; at the same time, low-cost carriers may actively participate and support local tourism development, start priority design tourist routes from national 5A level attractions, top tourism city, national top tourism towns. Cooperate with local tourist administration launch tourism marketing and customer behavior researches by taking advantage of low-cost carriers' resources, in order to develop regional tourism with speed.

\section{Conclusion}

Macau, as a tourist city, aviation industry plays an important role, with the successful of application for the list of world heritage and exhibition industry developing in recent years, new opportunities come up for Macau aviation industry development. Relying on gaming tourism industry, the gradually developing of meeting exhibition, amusement, shopping, as a whole cultural tourism, step into diversified development. If the fifth navigation can be introduced, a real sense of "open skies", Macau aviation industry hence to break through the bottleneck of development, and touch with the new starting point--taking off.

In short, not only developing low-cost carriers' help air travel transform from aristocratic to popularize, achieve the requirement of market segment, but also is the revolution of the entire air industry. Low-cost carriers enrich the air transportation market, stimulate the two-way development of both industry chain as well as consumption chain. 


\section{References}

Duan, M. (2013). Low cost aviation market competition-Sink or Swim. Journal of Macau Civil Aviation, 20, 52-56.

Fang, X. (2013). An overview of the diversified development strategy of Macau International Airport. Journal of Macau Civil Aviation, 20, 10-15.

Fang, X. (2014). The year's development in Macau of low-cost carriers. Journal of Macau Civil Aviation, 26, 13-18. http://dx.doi.org/10.1016/j.retrec.2014.01.001

Illustrate handbook of Macau civil aviation. 2012.

Lin, Q., \& Li, W. (2010). The future development strategy of Macau air transport industry. Journal of Air Transport \& Business. http://dx.doi.org/10.1177/004728759403200401

Ma, H. (2013). The market development of Macau and Pearl River Delta. Journal of Macau Civil Aviation, 22, 1-7. http://dx.doi.org/10.2307/3147108

Macau Civil Aviation Society. (2011). November. Journal of Air Transport \& Business.

Macau included in the top ten tourist areas this year. 2015, March 02. Hao Jiang Daily.

Shan, Z. (2016). Open sky for more international customers. Civil aviation forum.

The competitive low-cost route of Macau and Taiwan. May 11, 2015. Hao Jiang Daily.

Xu, S. (2012). The strategy development of airport and low-cost carriers. Journal of Macau Civil Aviation, 16, 34-35. http://dx.doi.org/10.1016/j.jairtraman.2012.10.006

Yuan, L. (2008). The influence of the development of low-cost carriers' market distribution to inbound tourists in Macau. Journal of Macau Civil Aviation, 7, 38-41. http://dx.doi.org/10.1080/02508281.1996.11014758

Zeng, Y. (2010). Discussion on the prospect of low cost aviation market in Macau. Journal of Macau Civil Aviation, 11, 6-10. http://dx.doi.org/10.1016/j.retrec.2010.01.001

Zhang, F. (2014). The competition and survival of Asia low-cost carriers. Journal of Macau Civil Aviation, 25, 1-9. http://dx.doi.org/10.1016/j.jairtraman.2003.10.009 